\title{
Evaluation of Economic, Social Effects of Renewable Energy Technologies
}

\author{
Lucio Laureti, Marco Giuseppe Lupis Rogges, Alberto Costantiello \\ Department of Economics, LUM Jean Monnet, Bari, Italy \\ Email: laureti@lum.it,marco_lupis@yahoo.it, costantiello@lum.it
}

How to cite this paper: Laureti, L., Rogges, M.G.L. and Costantiello, A. (2018) Evaluation of Economic, Social Effects of Renewable Energy Technologies. Journal of Environmental Protection, 9, 1143-1154. https://doi.org/10.4236/jep.2018.911071

Received: August 23, 2018

Accepted: October 12, 2018

Published: October 15, 2018

Copyright $\odot 2018$ by authors and Scientific Research Publishing Inc. This work is licensed under the Creative Commons Attribution International License (CC BY 4.0).

http://creativecommons.org/licenses/by/4.0/ (c) (i) Open Access

\begin{abstract}
What is sustainability? Does it only concern the environment or even socio-economic policies? It is only a question of ethics or a redefinition of industrial policy oriented towards the use of renewable energy, it can bring benefits both atmospheric and social employment. The need for the development of renewable sources can be in tune with the correct management of the territory in consideration of the fact that these sources involve the widespread implementation of small and medium-sized plants. A model of economic development based on renewable sources should respect the peculiarities and characteristics of the territories involved. It should also think of the territory as a "value" to be strengthened and used in a sustainable and integrated way and no longer as a passive platform on which to install plants. Solar thermal and photovoltaic, biomass, geothermal, hydrological, wind power are some of the sources the various countries must constantly invest. This publication is based on these concepts starting from an analysis of the employment data of the OECD "Organisation for Economic Co-operation and Development countries", comparing them successively with the results of renewable energy productivity. The analysis was performed by analyzing a sample of 22 countries over a period of 20 years, after which the regression curve for the variables with the OLS method was created. This econometric method has allowed us to analyze the impact that renewable technologies have on the parameters of social welfare and in particular on unemployment.
\end{abstract}

\section{Keywords}

Renewable Energy Sector, Unemployment, Panel Unit Roots Causality, Fixed Effects Model, Social Effects, Sustainability

\section{Introduction}

Human needs are infinite and go beyond the concerns of income and expense. 
The representation of the well-being [1] of a country can not only be dictated by economic measures, in fact it can even be misleading. It is important to outline the importance of the link between economic growth and unemployment, starting from the centrality of economic growth with particular attention to social inclusion and environmental sustainability [2]. Today, more than ever, after years of economic recession, every government must rethink its economic policy, moving away from a vision geared solely to GDP. The economic challenge of each country must be the use of policies oriented towards concrete improvement. Sustainability is a conception of development able to ensure the satisfaction of the needs of present generations without compromising that of future generations [3]. This condition is realized when important economic variables are respected such as the public budget and inflation and unemployment, and that the environment is safeguarded. Until the early 2000s this condition was mostly left in the background because the only priority was the improvement of living standards. Today, however, this condition has become a necessity and an emergency both because of the global warming and climate change, the ozone hole, the melting of the glaciers, the pollution of the seas of energy saving and the continuous difficulty of filling the gap. Unemployment in many parts of the world, especially in the advanced countries the problem that is becoming predominant is the growing inequality that can be attributed to globalization and new technologies, not only in income among people but also in business performance. We are facing with situations in which a few large companies are easily able to hire people, but mostly struggle to hire and rely more and more on tax and tax incentives to hire new, perhaps productive ones.

From Figure 1 it seems clear that the situation of the prospects of global wellbeing is not encouraging, since 2012 the number of unemployed has gone from little more than 190 million to almost 220 million. "For a correct assessment of sustainability and social well-being it is important to identify indicators

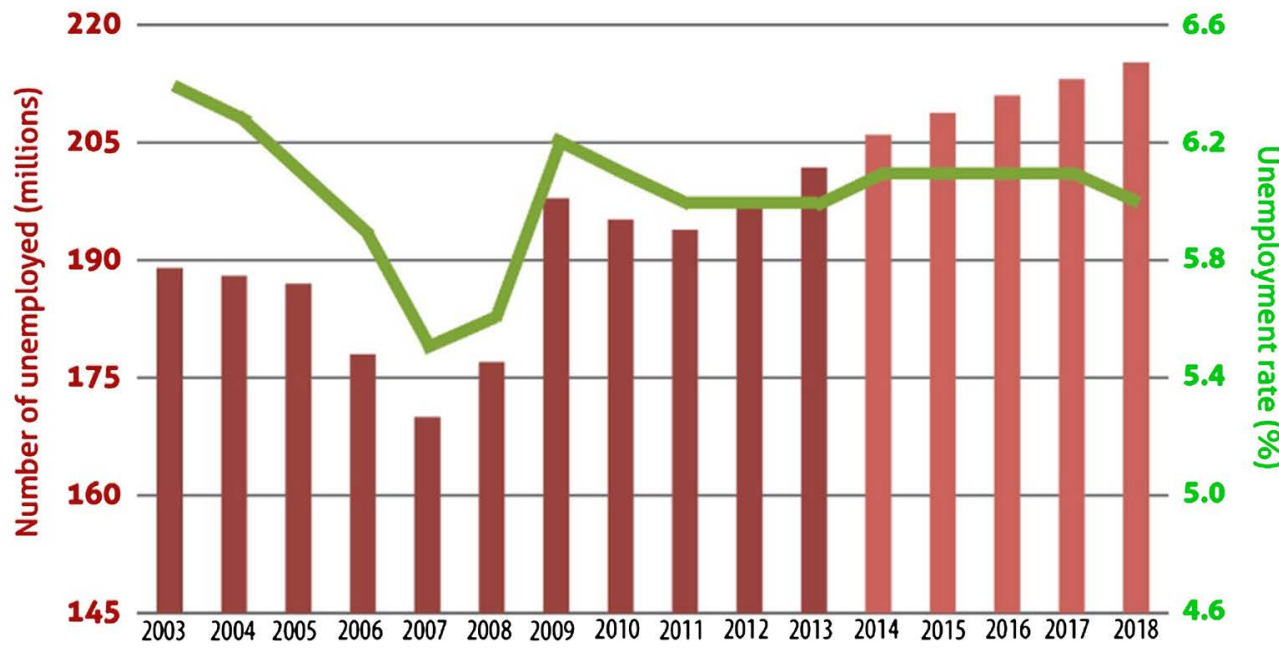

Source: ILO Economic Trend.

Figure 1. Global unemployment. 
that indicate measures $c$ to face the challenges and problems. Sustainability indicators identify relationships between the economy, environmental management and society and suggest approaches to tackling problems" [1].

Figure 2 shows the relationships between:

- the natural resource base provides the materials for production on which jobs and profits depend;

- employment affects wealth creation, living standards and poverty rates;

- poverty concerns crime, social unrest and instability;

- the quality of resources, air and water affects health;

- the resources used for production influence profits.

"For example, health problems affect worker productivity and health insurance costs, and poor water quality before use in a process that requires clean water requires extra spending and lower profits associated with water treatment. Many traditional indicators are not holistic, like the gross domestic product (GDP), which measures the amount of money spent in a country. GDP is generally considered a measure of the economic well-being of a country, based on the presumption that the greater the money spent, the greater the GDP and the better the economic well-being, although this indicator reflects only the amount of economic activity, regardless of how this activity affects the social and environmental well-being of the community" [1].

Sustainability as clearly seen in Figure 2 is always the result of social, economic

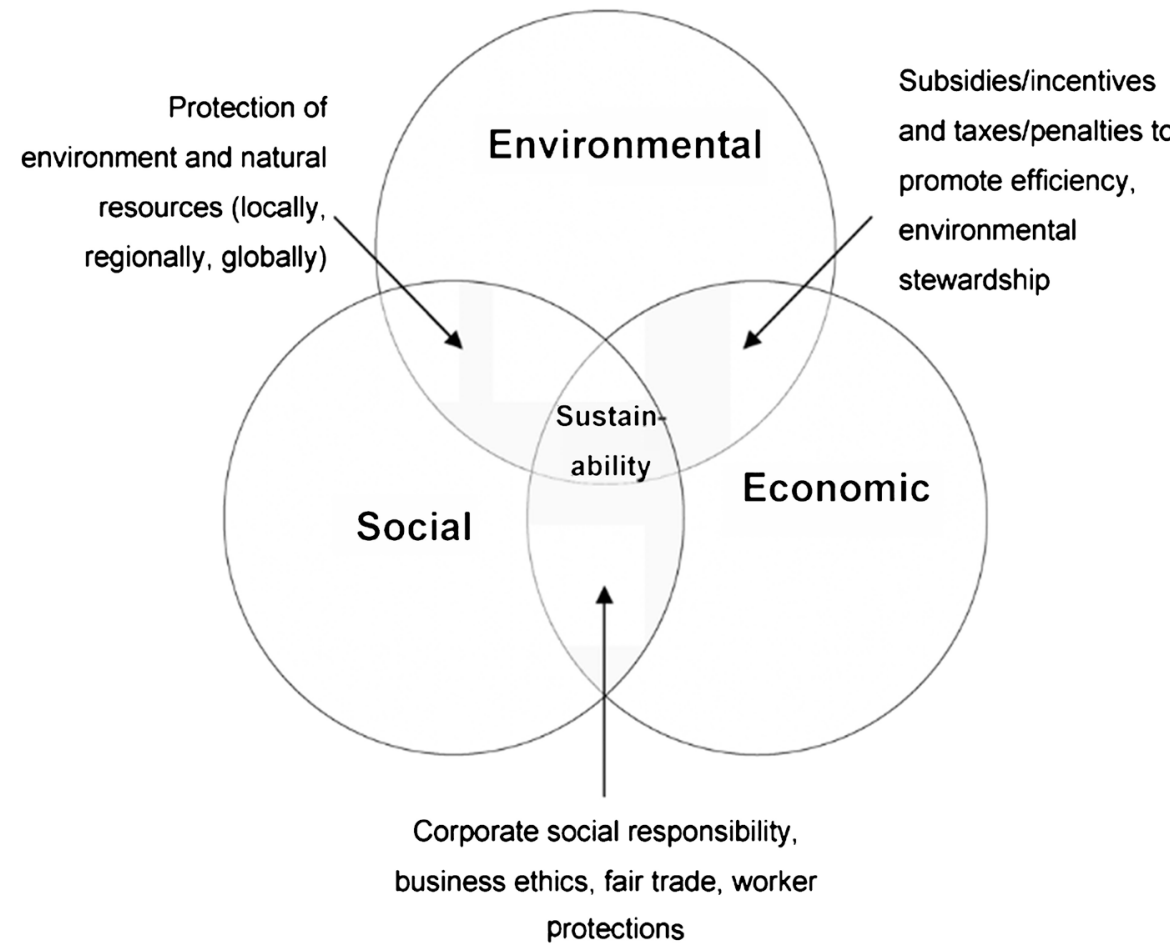

Source: Sustainable Manufacturing and Design: Concepts, Practices and Needs "Marc A. Rosen and Hossam A. Kishawy".

Figure 2. Sustainability as the intersection of its three key parts, and examples of features at the intersection of any two parts. 
and environmental variables. If countries are able to have high standards of these factors, there is a good level of sustainability in the world [4].

\section{Literature Review}

Already at the beginning of the 70s Tibor Scitovsky argued that our economic well-being is constantly increasing but as a result the population is no longer happy. In some cases happiness and income do not vary together and within a country, in fact there is not always a significant and robust correlation between income and subjective well-being. Well-being in the broad sense has become the subject of discussion in the academic field and a topic of reflection for policy makers. The analysis and forecasting of economic phenomena required a constant effort to simplify the reality that has become increasingly complex over the years. Already since the thirties, years of the Great Depression, the factors that have led to the inclusion of increasing complexity are basically two: the Great Recession triggered by the 2008 crisis which has led to a re-evaluation of the intuitions of the economist Hyman Minsky, one of the first scholars to consider the importance of the financial sector to explain the business cycle; and the increased inequalities with economic developments [5]. A conceptual framework proposed by the OECD and based on the Amartya Sen capacity approach defines progress in terms of increasing fair and sustainable well-being. The quality of life depends not only on the available economic resources, but also on other important variables [6]. Human well-being is divided into nine dimensions: income and wealth, work and retribution, living conditions, health, life-work, education, civic engagement, environmental quality and personal safety. Based on these dimensions, the OECD used a set of indicators [7] to build the Better Life Index. The search for an index that more accurately measures well-being leads to rethinking the role of indicators based mainly on income levels, the assessment, in fact, cannot ignore the equitable distribution of material and immaterial resources, it is important to evaluate the index of Gini. In 1993 Stern estimated a VAR for GDP, capital, labor, and a Divisia index of energy use, finding that energy Granger caused GDP [8]. It is important to underline that the progressive technological evolution inevitably generates problems of social sustainability both in terms of employment levels and inequalities and above all of the training needs of the workforce [9]. The interaction of human activities with the environment is continuous, inevitable. The developed countries have based their model of economic growth on the diffusion of consumer goods and services that require an intense use of energy, often to the detriment of the environment and with little regard for the future availability of non-renewable energy sources [10]. For Ryder, historically Europe has focused on improving labor productivity while neglecting energy and resource productivity. Over the last 50 years, labor productivity has quadrupled, while energy has grown less than $25 \%$. Green tech is prevalently in the hands of SMEs, but both SMEs and larger companies have the problem of finding workers with the right skills in the green economy. 
As early as 1984 [3] [11], Parafit started talking about Social Welfare, identifying the highest level of well-being in the possibility of satisfying material, social and psychological needs. In 1971 Rawls elaborated a more complex concept of well-being by developing an index of primary goods that included rights, freedom and opportunity, income and wealth, and the basis of personal respect. Harsanyi in 1996 hypothesized that an improvement in well-being, implicitly and necessarily depends on an improvement in income that gives the opportunity to increase choice and satisfy more desires [12]. The concept of sustainability stems from the Brudland report of 1987 and was subsequently used in many researches by elaborating more than 50 concepts of sustainability using a plurality of approaches [13]. In the mid-1970s, economists began to elaborate concepts concerning the relationship between non-renewable resources and economic growth, for example, the research of Solow in 1974, and Stiglitz in 1974 [14] [15]. The aim of sustainable wellbeing is the possibility of avoiding a depletion of resources also for future generations. In 1977 Hartwick hypothesized that the depletion of resources is directly proportional to the level of capital investment [16].

The economics literature contains several scientific researches that investigate the impacts of renewable energy policies on employment [17] [18]. In 2006, Hillebrand studied the contribution of environmental sustainability policies to economic developers in Germany. Lehr et al. (2008) [13] use a similar model to demonstrate that the net effect of the renewable energy [19] support policies in Germany is positive, such that the policy lowers the long-run rate of unemployment. Ragwitz et al. (2009), gives a further contribution to research, in fact, estimate that EU-wide renewable energy support policies have generated a net positive impact on employment [20]. Other studies employ a computable general equilibrium model to assess the impacts of renewable electricity policies on employment. Chontanawat et al. (2006) examined causality between energy consumption and GDP [21] using data for 108 countries [22]. Bovenberg and de Mooij in 1994 [23] use a simple general equilibrium model with labor-leisure choice to explore the impacts of a labor to dirty goods tax shift on employment and non-environmental welfare [24]. They find that the relatively narrow base of the environmental tax implies that the dirty goods tax is more distorting than the labor tax, and results in a fall in the real wage, and consequently a reduction in employment. Schneider in 1997 [25] studied the impact of unemployment, and concludes that a shift towards environmental taxation is likely to reduce unemployment.

Figure 3 clearly shows that the production of renewable energy in the last few years has grown more and more, especially in the Eastern countries and in the OECD European countries.

\section{Methodology}

\section{Research Question}

- Is there a relationship between renewable energy and unemployment? 


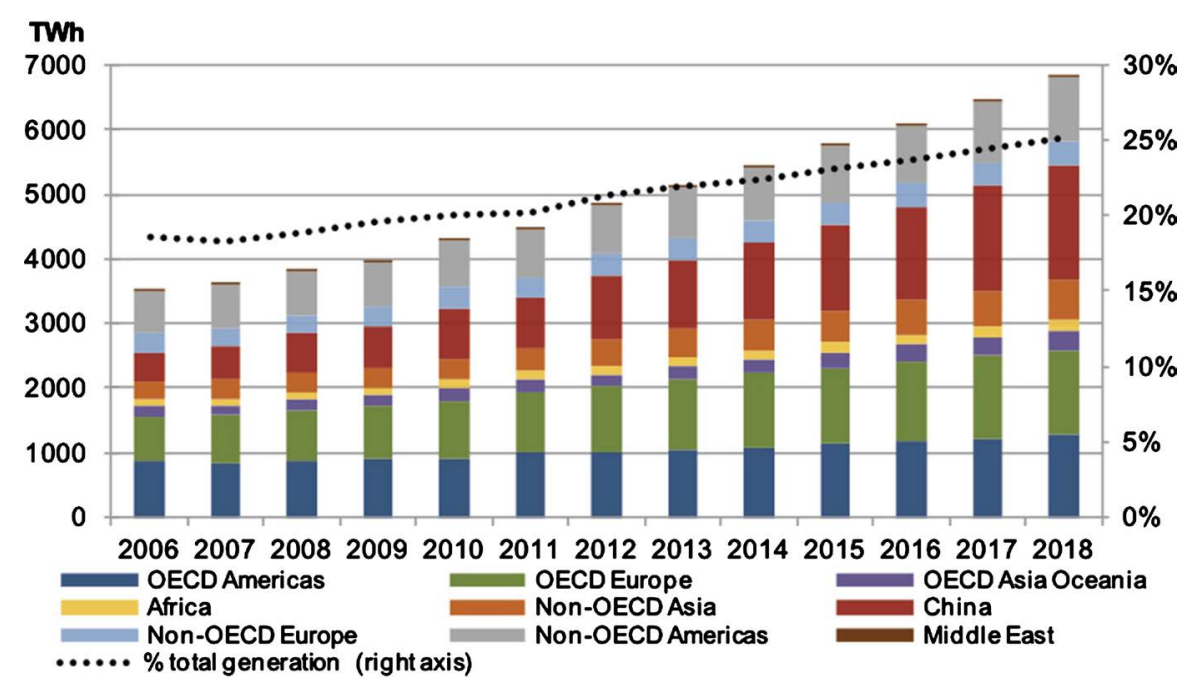

Source: International Energy Agency (IEA).

Figure 3. Global renewable energy production by region.

- Renewable energy will contribute to the development of a nation and especially the reduction of unemployment.

The methodology adopted [26] for this study followed the following step:

- Creation of a 1 panel with 11 OECD countries a bow time goes from 1990 to 2013.

Dependent Variable: Unemployment.

Independents Variables: Economics Variables and Renewable Energy Productions Variables.

For this panel is been adopted the following methodologies to analyze the relationships between the dependent variables and independent variables:

A-Creation of the regression curve for the variables with OLS Method [27].

To analyze the impact that renewable technologies have on parameters of social well-being, and particularly on unemployment, in a sample of 11 OECD nations, it was decided to use the least-squares OLS estimator which is a widely used model to estimate parametric models. This model is very useful because it allows to reduce the square of the distances between the available observations [28] [29].

The $\beta$ estimate is chosen to make the residues smaller. In this research, more observations were analyzed over a period of 20 years, so the regression model used is represented by the following [30] OLS model:

$$
y_{i}=\beta_{0}+\sum_{j=1}^{p} \beta_{j} X_{i j}
$$

where $y$, which is the dependent variable, is represented by the unemployment rate while $\beta$ is the estimator vector [31] [32].

\subsection{Data Set Analysis}

The Data Set Analysis in formed on 11 OECD countries. The countries included in the OECD group are fairly homogenous. The dataset constructed combines different sources. For the energy sector, we collected data on energy balances 
from the publications of the OECD, data that contains annual data on final energy consumption for the whole economy and for major sectors such as industry, commerce and public services, transport and residential sectors. All information on the economic performance in the different sectors is taken datasets from the World Bank World Development Indicators (WDI), from IEA Statistic Database (Energy Balance of OECD Countries), from World Energy Council (Energy Efficiency Indicators database), from IRENA database, from REN 21 Database and from World Employment Social Outlook.

OECD: Norway, Australia, United States, Netherlands, Germany, Ireland, Sweden, Switzerland, Japan, Italy, Mexico.

\subsection{Indicators}

The indicators used, can be divided into two categories. In the first category are economic indicators that are intended to inform on the progress of an economy. In the second category we find energy indicators belonging both to renewable energies and fossil energy. In the panel the following variables have been included: UNEMPLOYMENT as dependent variable and Terms of trade adjustment, Net of Hydropower Production, Net production of Biomass Energy, Net of Wind Production, Net of Solar Energy Production, Gross Heat Content of Biomass and Waste Electric Power, Gross Heat Content of Geothermal Electric Power, Gross Heat Content of Hydroelectric Power, Gross Heat Content of Hydroelectric Power, Gross Heat Content of Solar Electric Power, Gross Heat Content of Wind Electric Power, GDP and Foreign direct Investment as independent variables. All variables used for the research model are showed in Table 1. Each variable was analyzed with a unit of measurement in line for all, and each was retrieved from reliable and certified sources such as the World Bank and the U.S. [33] Energy Information Administration (EIA) [34].

The Panel created, gave satisfactory results, in fact, showed that there are no missing observations. Thanks to the use of the model Panel, the degrees of freedom obtaining a Panel $\left(\mathrm{N}^{\star} \mathrm{T}\right)$ observations increased which, thus allowed the estimation of further observations [35] [36].

\section{Analysis of Relationship between Unemployment and Renewable Energy Variables}

Table 2 shows the specifications of orders and deterministic part of the OLS [37] model through various analyzes that are more suitable results to pursue the object of study, in particular for tracked observations. It can easily notice that already in the OLS model is a clear inverse relationship between the variable UNEMPLOYMENT and SEP.

The model is also very reliable because the p-value of the different variables is particularly low, while R-squared is high.

From this graph it became clear that there isn't an inverse relationship between unemployment factor and solar. In fact: 
Table 1. Variables list.

\begin{tabular}{|c|c|c|c|c|}
\hline VARIABLE & TYPE & UNITS OF MEASUREMENT & ACRONYM & SOURCE \\
\hline Unemployment & Economic & & UNM & $\begin{array}{l}\text { WorldBank } \\
\text { ILO estimate }\end{array}$ \\
\hline Terms of tradeadjustment & Economic & Constant LCU & TAD & WorldBank \\
\hline Direct Investment & Economic & Million Dollar & FDI & WorldBank \\
\hline GDP & Economic & Million Dollar & GDP & WorldBank \\
\hline Net of Wind Energy Production & Energy & Billion Kilowatthours & WEP & Eia \\
\hline Net of Solar Energy Production & Energy & Billion Kilowatthours & SEP & Eia \\
\hline Gross Heat Content of Biomass and Waste Electric Power & Energy & BTU Per Kilowatt hour & GHB & Eia \\
\hline Gross Heat Content of Geothermal Electric Power & Energy & BTU Per Kilowatt hour & GHG & Eia \\
\hline Gross Heat Content of Hydroelectric Power & Energy & BTU Per Kilowatt hour & $\mathrm{GHH}$ & Eia \\
\hline Gross Heat Content of Solar Electric Power & Energy & BTU Per Kilowatt hour & GHS & Eia \\
\hline Gross Heat Content of Wind Electric Power & Energy & BTU Per Kilowatt hour & GHW & Eia \\
\hline Energy Consume & Energy & Quadrillion_Btu & EC & Eia \\
\hline Natural Gas Production & Energy & Billion Cubic Feet & GP & Eia \\
\hline Total Oil Supply & Energy & Thousand Barrels Per Day & OSS & Eia \\
\hline Total Primary Coal Production & Energy & Thousand Short Tons & TCP & Eia \\
\hline Total Energy Import & Energy & & TEI & Word Bank \\
\hline
\end{tabular}

Table 2. OLS method.

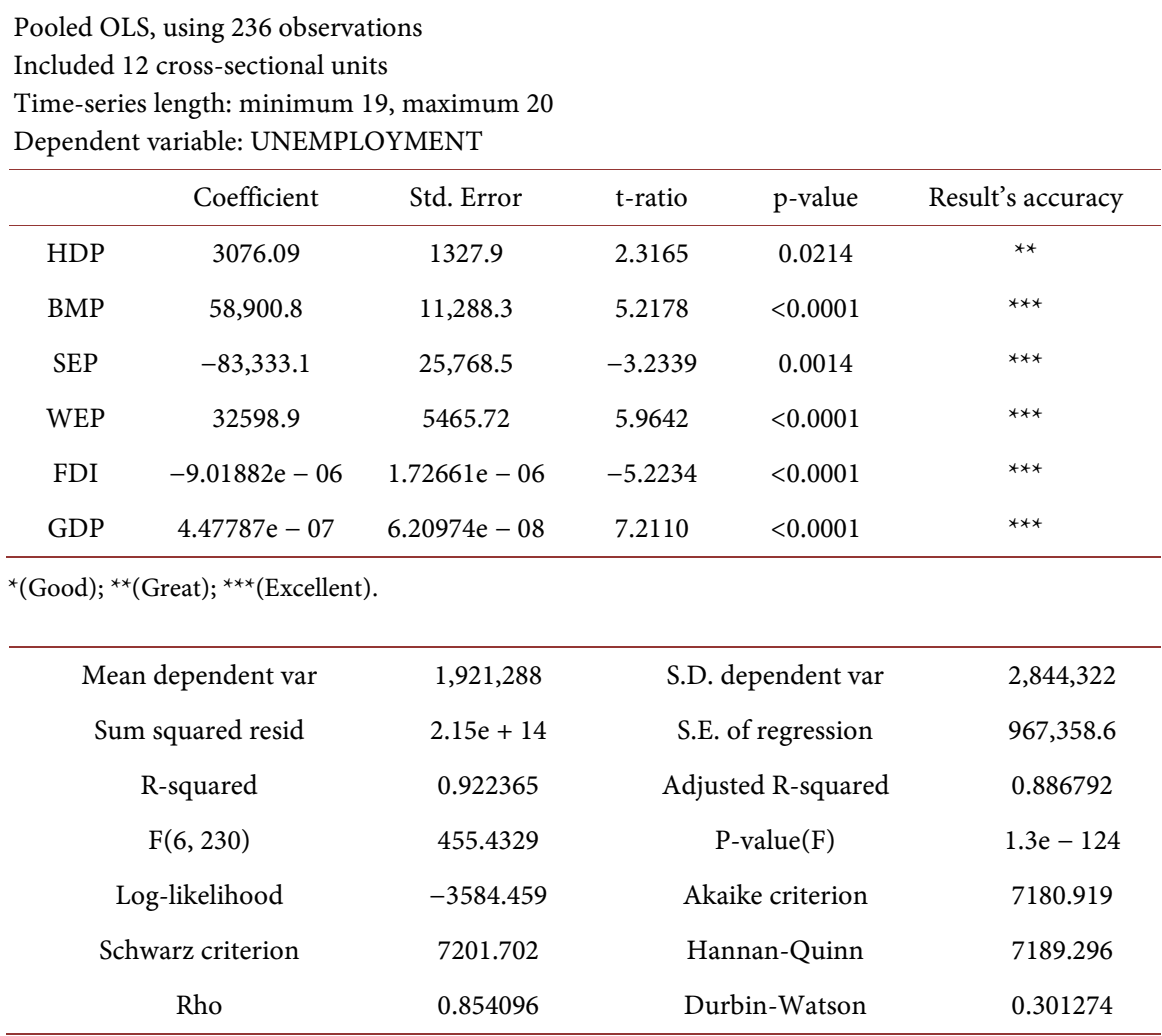

Non-linearity test (squares)-Null hypothesis: relationship is linear; Test statistic: $\mathrm{LM}=64.5237$; with $\mathrm{p}$-value $=\mathrm{P}($ Chi-square $(6)>64.5237)=5.39659 \mathrm{e}-012$. 
- SEP (Solar Energy Production): Coefficient -83,333,1 with ${ }^{\star * *}$.

While all other variables (Hydroelectric, Geothermal and Wind) have a positive value and then means they have a direct relationship.

Furthermore, is important the direct relationship between GDP and Unemployment, because it evidence that there isn't positive impact between Renewable Energy Variables, and Unemployment.

\section{Conclusions}

Equity, distribution, health, education, environmental sustainability are now recurrent concepts in the economic debate and not just political. Today, talking about sustainability is also equivalent to saying new investments and new profitable businesses; just think of the Tesla case which imposed the electric motor as the standard of the future for all the major car manufacturers in the world. A growing share of global financial investments is occupied by jobs in sectors and businesses that use sustainability as a selection criterion for their activities, based on social and governmental environmental factors.

This research focuses on socio-political aspects related to the energy sector over a 25-year period in OECD countries such as Norway, Australia, United States, Netherlands, Germany, Ireland, Sweden, Switzerland, Japan, Italy, Mexico. In the processed data panel, we have related, as a dependent variable, the level of unemployment, while as independent variables, energy and economic ones, to study the impact they have on the economic growth of non-OECD countries.

The literature shows that the increase in unemployment mainly depends on economic variables such as GDP [38] [39]. In this research, the effects of GDP have been isolated with an OLS analysis that shows a direct relationship between the variation in GDP and the unemployment rate, in this way we have been able to isolate the effects of these ones by giving greater importance to energy variables.

OLS model has a relevant significance on all energy variables, in particular it is inferred that there is a Reverse relationship between Unemployment and Solar Energy with a p-value 0.0014 . This last result is demonstrated by the fact that for both energy sources, considered as chain and working sub-sectors, also have effects on the level of unemployment, particularly on medium skilled workers. GDP does not affect unemployment, as the variation in GDP has had a significant impact mainly on capital intensive sectors, but investment change has a positive impact on unemployment. Concluding, it is possible to confirm that renewable energy from biomass and solar energy creates indirect and induced effects that have a positive effect on the OECD countries' economies, and in particular contribute to the reduction of unemployment. Given the result of this work and pointing out that Solar sectors have a positive effect on the unemployment rate, the indication of Policy on the countries involved calls out for a strengthening of investments in these sectors as each investment in this imply a 
Reduction of Unemployment.

\section{Conflicts of Interest}

The authors declare no conflicts of interest regarding the publication of this paper.

\section{References}

[1] Dolan, P., Knight, M., Metcalfe, R., Peasgood, T. and White, M. (2007) The Relationship between Well-Being and Sustainable Development.

[2] Yoo, S.-H. (2006) The Causal Relationship between Electricity Consumption and Economic Growth in the ASEAN Countries. Energy Policy, 34, 3573-3582. https://doi.org/10.1016/j.enpol.2005.07.011

[3] Yu, E.S.H. and Wang, B.K. (1984) The Relationship between Energy and GNP: Further Results. Energy Economics, 6, 186-190. https://doi.org/10.1016/0140-9883(84)90015-X

[4] Jenner, S., Chan, G., Frankenberger, R. and Gabel, M. (2010) What Drives States to Support Renewable Energy. The Energy Journal, 33, 1-12.

[5] Aqeel, A. and Butt, M.S. (2001) The Relationship between Energy Consumption and Economic Growth in Pakistan. MPRA Paper.

[6] Ferguson, R., Wilkinson, W. and Hill, R. (2000) Electricity Use and Economic Development. Energy Policy, 28, 923-934. https://doi.org/10.1016/S0301-4215(00)00081-1

[7] Fatai, K., Oxley, L. and Scrimgeour, F.G. (2004) Modelling the Causal Relationship between Energy Consumption and GDP in New Zealand, Australia, India, Indonesia, Philippines and Thailand. Mathematics and Computers in Simulation, 64, 431-445. https://doi.org/10.1016/S0378-4754(03)00109-5

[8] Stern, D.I. and Enflo, K. (2013) Causality between Energy and Output in the Long-Run. Energy Economics, 39, 135-146. https://doi.org/10.1016/j.eneco.2013.05.007

[9] Lee, C.C. (2006) The Causality Relationship between Energy Consumption and GDP in G-11 Countries Revisited. Energy Policy, 34, 1086-1093. https://doi.org/10.1016/j.enpol.2005.04.023

[10] Loschel, A. (2002) Technological Change in Economic Models of Environmental Policy: A Survey. Ecological Economics, 43, 105-126.

[11] Yu, E. and Choi, J.Y. (1985) The Causal Relationship between Energy and GNP: An International Comparison. Journal of Energy Finance \& Development, 10, 249-272.

[12] Yamusa II, S.U. and Ansari, A.H. (2013) Renewable Energy Development in Two Selected African Countries: An Overview and Assessment. Australian Journal of Basic and Applied Sciences, 7, 151-153.

[13] Kraft, J. and Kraft, A. (1978) On the Relationship between Energy and GNP. Journal of Energy and Development, 5, 326-331.

[14] Chontanawat, J. (2013) Modelling the Causal Relationship between Energy Consumption and Economic Growth in Asia. University of Technology Thonburi, Krung Thep Maha Nakhon.

[15] Chontanawat, J., Hunt, L.C. and Pierse, R. (2006) Causality between Energy Consumption and GDP: Evidence from 30 OECD and 78 Non-OECD Countries. University of Technology Thonburi, Krung Thep Maha Nakhon. 
[16] Lee, C.C. (2005) Energy Consumption and GDP in Developing Countries: A Cointegrated Panel Analysis. Energy Economics, 27, 415-427. https://doi.org/10.1016/j.eneco.2005.03.003

[17] Dantama, Y.U., Abdullahi, Y.Z. and Inuwa, N. (2012) Energy Consumption-Economic Growth Nexus in Nigeria: An Empirical Assessment Based on ARDL Bound Test Approach. European Scientific Journal, 8, 141-157.

[18] Economic Consulting Associates (2014) Correlation and Causation between Energy Development and Economic Growth. Department for International Development.

[19] Razzaqi, S. and Sherbaz, S. (2011) Dynamic Relationship between Energy and Economic Growth: Evidence from D8 Countries. The Pakistan Development Review, 50, 437-458. https://doi.org/10.30541/v50i4IIpp.437-458

[20] Abosedra, S. and Baghestani, H. (1989) New Evidence on the Causal Relationship between U.S. Energy Consumption and Gross National Product. Journal of Energy Development, 14, 285-292.

[21] Shiu, A. and Lam, P.-L. (2004) Electricity Consumption and Economic Growth in China. Energy Policy, 32, 47-54. https://doi.org/10.1016/S0301-4215(02)00250-1

[22] Jumbe, C. (2004) Cointegration and Causality between Electricity Consumption and GDP: Empirical Evidence from Malawi. Energy Economics, 26, 61-68. https://doi.org/10.1016/S0140-9883(03)00058-6

[23] Nielsen, S.B., Pedersen, L.H. and Sorensen, P.B. (1995) Environmental Policy, Pollution, Unemployment, and Endogenous Growth. International Tax and Public Finance, 2, 185-205. https://doi.org/10.1007/BF00877496

[24] Asafu-Adjaye, J. (2000) The Relationship between Energy Consumption, Energy prices and Economic Growth: Time Series Evidence from Asian Developing Countries. Energy Economics, 22, 615-625. https://doi.org/10.1016/S0140-9883(00)00050-5

[25] Schneider, K. (1997) Involuntary Unemployment and Environmental Policy: The Double Dividend Hypothesis. The Scandinavian Journal of Economics, 99, 45-59. https://doi.org/10.1111/1467-9442.00046

[26] Granger, C.W.J. (1969) Investigating Causal Relations by Econometric Models and Cross-Spectral Methods. Econometrica, 37, 424-438. https://doi.org/10.2307/1912791

[27] Hill, R.C., Griffiths, E.W. and Lim, G.C. (2008) Principles of Econometrics. Wiley, New York.

[28] Maddala, G.S. and Wu, S. (1999) A Comparative Study of Unit Root Tests with Panel Data and a New Simple Test. Oxford Bulletin of Economics and Statistics, 61, 631-652. https://doi.org/10.1111/1468-0084.61.s1.13

[29] Toda, H.Y. and Yamamoto, T. (1995) Statistical Inference in Vector Autoregressions with Possibly Integrated Processes. Journal of Econometrics, 66, 225-250. https://doi.org/10.1016/0304-4076(94)01616-8

[30] Di Maria, C. and Valente, S. (2006) The Direction of Technical Change in Capital-Resource Economies. Economics Working Paper Series 06/50, ETH Zurich.

[31] Granger, C.W.J. (1988) Causality, Cointegration and Control. Journal of Economic Dynamics and Control, 12, 551-559. https://doi.org/10.1016/0165-1889(88)90055-3

[32] Im, K.S., Persaran M.H. and Shin Y. (2003) Testing for Unit Roots in Heterogeneous Panels. Journal of Econometrics, 115, 53-74. https://doi.org/10.1016/S0304-4076(03)00092-7

[33] Salim, R., Rafiq, S. and Hassan, K. (2008) Causality and Dynamics of Energy Con- 
sumption and Output: Evidence from Non-OECD Asian Countries. Journal of Economic Development, 33, 1-26.

[34] Vlahinic-Dizdarevic, N. and Zikovic, S. (2010) The Role of Energy in Economic Growth: The Case of Croatia. Zbornik Radova Ekonomskog Fakultet au Rijeci, 28, 35-60.

[35] Engle, R.F. and Granger, C.W.J. (1987) Cointegration and Error Correction: Representation, Estimation and Testing. Econometrica, 55, 251-276. https://doi.org/10.2307/1913236

[36] Dickey, D. and Fuller W. (1979) Distribution of the Estimators for Autoregressive Time Series with a Unit Root. Journal of the American Statistical Association, 74, 427-431.

[37] Westerlund, J. and Edgerton, D.L. (2008) A Simple Test for Cointegration in Dependent Panels with Structural Breaks. Oxford Bulletin of Economics and Statistics, 70, 665-704. https://doi.org/10.1111/j.1468-0084.2008.00513.x

[38] Mihajlović, B. (2011) Alternative Energy Sources as an Important Factor of Serbia's Economic Development.

[39] Gbadebo, O., Odularu, G.O.A. and Okonkwo, C. (2009) Does Energy Consumption Contribute to Economic Performance? Empirical Evidence from Nigeria. Journal of Economics and International Finance, 1, 44-58. 